\title{
Access, Asylum and Atrocities: An Unholy Alliance?
}

\author{
JoSEPH RiKHOF
}

\begin{abstract}
This article explores the international and Canadian dimensions of the crossroads between criminal law on one hand and the immigration and refugee law on the other, with special emphasis on the regulation and jurisprudence regarding criminal activities such as terrorism, organized crime, genocide, war crimes, and crimes against humanity. In addition to examining the context of international policy and the international criminal law in this area, the article also describes in detail the Canadian case-law in relation to the sections in the Immigration Act that address these types of serious criminality, such as the admissibility provisions and the exclusion clauses. At the same time, the policy of the Canadian government is coming to grips with its international obligations when dealing with persons involved in such criminal activities.
\end{abstract}

\section{Résumé}

Cet article explore les dimensions canadiennes et internationales du carrefour où se croisent d'une part la loi criminelle, et de l'autre, la loi sur l'immigration et le droit d'asile, avec une emphase toute particulière sur les règlements et la jurisprudence concernant les activités criminelles, comme le terrorisme, la criminalité organisée, le génocide, les crimes de guerre et les crimes contre l'humanité. En sus d'un examen du contexte politique international et $d u$ droit criminel international dans ce domaine, l'article décrit aussi dans les détails la jurisprudence canadienne concernant les sections de la Loi sur l'immigration qui s'adressent à ce type de criminalité grave, telles que les provisions sur l'admissibilité et les clauses d'exclusion. Par la même occasion, l'article discute de la politique du gouvernement canadien face à ses obligations internationales en ce qu'il s'agit de personnes impliquées dans de telles activités criminelles.

\section{Introduction}

C anada is, on the whole, a welcoming place for refugees and immigrants, and many deserve this welcome. Many, but not all. Among the people who want to come to Canada because of their genuine fear of persecution in the country of origin or to seek a better life, there are some whose backgrounds are suspect because they are serious criminals. Their number is not high; only a small percentage of them are investigated because of a possible criminal past. ${ }^{1}$ However, because of the seriousness of the allegations (war crimes, genocide, crimes against humanity, terrorism, organized crime) and the high-profile, emotionally charged nature of the proceedings dealing with these allegations, the impact of cases involving criminal refugee claimants and immigrants goes far beyond their small number.

While immigration policy has always been international in outlook, the law underlying this policy has until recently been much more parochial, regulating access and asylum primarily from a domestic perspective. This has changed in the last decade, especially when dealing with criminals. More and more aspects of international criminal law have found their way into the Immigration Act, either directly by reference to international law concepts in its provisions or indirectly as a result of the jurisprudence of the Federal Court. This article intends to comprehensively examine the aspects of international criminal law that have had or will have an important impact on immigration and refugee law: the regulation of war crimes, crimes against humanity, genocide, terrorism, and organized crime.

There exists a vast discrepancy, internationally and in Canada, in the amount of attention given to the crimes discussed in this article. The approach taken to war crimes and crimes against humanity has progressed the furthest in that the prohibition of these crimes has been the subject 
of a comprehensive legal regime and of widespread international and national enforcement. In contrast, the regulation of terrorist activities has been piecemeal and in response to specific crises, with no possibility at the moment for international adjudication, ${ }^{2}$ while legally targeting organized crime internationally is still in its infancy. This discrepancy, which extends in Canada also to the policy level, finds its reflection in this article, where most of the discussion will be about war crimes and crimes against humanity.

\section{International Crimes: An International Context}

\section{War Crimes and Crimes against Humanity}

There have always been war criminals; there have been war criminals as long as human beings have settled their political differences violently rather than peacefully. ${ }^{3}$ However, the manner in which society and the international community have dealt with persons who violated rules established for the conduct of war have differed over time. ${ }^{4}$ The last century, and especially the last couple of decades, have seen a remarkable change in attitudes and approaches towards people who commit atrocities such as war crimes and crimes against humanity.

While this is not the place for detailed discussion of the varied responses to war criminals (a term used here also for persons who were involved in genocide and crimes against humanity, and not only those who violated the rules of war), it is still useful to point out that since the Nuremberg trials after the Second World War, the international community and individual countries have developed a number of means to address the terrible turmoil caused by serious violations of human rights.

Persons who committed war crimes during the Second World War were initially criminally prosecuted by both the international military tribunals in Nuremberg and Tokyo, and by courts in Europe and Asia. This effort essentially ended by the early sixties, and little more was done until the eighties, when countries such as Canada, Australia, the United States, and the United Kingdom renewed their efforts to bring war criminals from that era to justice. Australia and the United Kingdom chose the route of criminal prosecution, while the United States placed its trust in revocation of citizenship and deportation for those who had gained their citizenship by misrepresenting their activities during the Second World War. In 1987 Canada decided to use both approaches.

On the whole it has become clear that in recent times prosecution of war criminals of the Second War has been less successful than the remedy of revocation and deportation. Of the fewer than ten prosecutions attempted in
Canada, Australia, and the United Kingdom in the last fifteen years, only one was successful, in the United Kingdom in 1999..$^{5}$ The success rate for the revocation/deportation approach has been much higher, ${ }^{6}$ especially in the United States.

The response to war crimes committed since the Second World War covers an even larger spectrum. There have been criminal investigations or prosecutions in Europe against the perpetrators of war crimes in Yugoslavia and the genocide in Rwanda; countries such as Switzerland, Germany, Denmark, Belgium, France, and the Netherlands come to mind. Other countries have started criminal proceedings against their own nationals who had been involved in crimes against humanity against fellow citizens during earlier regimes; Ethiopia has established the office of the special prosecutor for crimes committed during the Mengistu regime; Rwanda is trying tens of thousands of persons involved in the 1994 genocide; and in Chile the way has been cleared to prosecute Augusto Pinochet.

Internationally, the atrocities committed in Yugoslavia and Rwanda resulted in action by the United Nations Security Council, which set up specialized tribunals to apportion justice to the principal actors in these conflicts. These tribunals are the International Criminal Tribunal for the Former Yugoslavia (ICTY) and the International Criminal Tribunal for Rwanda (ICTR). There have been calls for other international tribunals to address crimes against humanity committed in places such as Cambodia, East Timor, and Sierra Leone.

A major step internationally in pursuing war criminals has been the Statute of the International Criminal Court of July $17,1998,7$ which gives the International Criminal Court jurisdiction to hear cases involving genocide, war crimes, and crimes against humanity without the territorial limitations now associated with the ICTY and ICTR. The Statute will come into force when sixty countries have ratified it, likely within the next couple of years. ${ }^{8}$

Still within the realm of criminal remedies have been two important developments in extradition law, both of which have to do with immunity for heads of state. Traditionally, heads or ex-heads of state cannot be prosecuted or extradited anywhere for any crime committed while functioning as head of state. An exception has now been made by the British House of Lords in the Pinochet case, ${ }^{9}$ and by the Iсту when it indicted Yugoslav President Milosevic. ${ }^{10}$ In both situations - that of former head of state Pinochet and of Milosovic, who was head of state at the time of indictment-it has now been accepted that immunity cannot be invoked when the crime is genocide, a war crime, or a crime against humanity. The result of these two 
developments has been that some (ex-) heads of state have considered it prudent not to leave their countries for fear of extradition requests. ${ }^{11}$ As well, in the Pinochet situation, Argentina and a number of European states, apart from Spain which initiated the original request for his extradition, also wanted him for trial in their countries.

A number of other, non-criminal, remedies are being employed to make life difficult for war criminals. Provisions in the immigration and refugee laws of European countries, Canada, Australia, and the United States are good examples of resorting to civil means to obtain some vindication for the victims of human rights abuses. However, these provisions and their effectiveness vary widely from country to country. Another course of action is pursued in the United States where perpetrators of atrocities must pay compensation to their victims. ${ }^{12}$

Last, a number of countries have confronted the past using an entirely different means: the route of truth and reconciliation commissions. They preferred a more contextual approach as opposed to bringing to justice a limited number of individuals. The best known are such commissions in South America (Bolivia, Uruguay, and Argentina in the eighties, and Chile in the nineties), Latin America (El Salvador and Guatemala in the nineties) and Africa (Uganda and Zimbabwe in the eighties, Chad, South Africa, and Rwanda in the nineties, and even more recently in Nigeria and possibly Sierra Leone), although there has also been such work done in the Philippines and Germany. ${ }^{13}$

Finally, sometimes more than one remedy has been employed to deal with atrocities. The Rwandan genocide resulted in the establishment of an international tribunal, prosecutions of its own nationals by Rwanda, prosecutions by other countries, deportations, transfers to the ICTR tribunal, and a truth and reconciliation commission. At the moment there are discussions about creating a mixed international/domestic tribunal in Sierra Leone, while also examining the possibility of a truth and reconciliation commission as well.

\section{Genocide}

While the international community has been the most active since the Second World War in dealing with war criminals, ${ }^{14}$ other serious criminal activities have also been the subject of international regulation and enforcement. The most important of these are the crimes of genocide, terrorism, organized crime, and torture. ${ }^{15}$

While the crime of genocide has been the subject of an international convention since 1948 and found to be part of customary international law by the International Court of Justice in $1951{ }^{16}$ no prosecutions of perpetrators of this crime occurred until 1996 when the ICTR charged Mr. Akeyesu $^{17}$ with this crime in the context of the 1994 genocide in Rwanda. Both the ICTY and ICTR have now used the genocide provision to lay charges against individuals involved in the Bosnian and Rwandan conflicts, ${ }^{18}$ as have a number of European countries. Germany has been particularly successful, with four convictions so far.

\section{Terrorism}

Terrorism has been used as a political tool to change the behaviour of governments for over a century, but only in the last couple of decades has it become the subject of treaties that held individuals liable under international law. Since 1968, several forms of terrorism have been prohibited by widely accepted international conventions: hijacking:, 19 unlawful acts of violence at airports; ${ }^{20}$ crimes against internationally protected persons; ${ }^{21}$ hostage taking; ${ }^{22}$ criminals acts in relation to the physical protection of nuclear materials $;{ }^{23}$ and unlawful acts against the safety of maritime navigation, including fixed platforms located on the Continental Shelf. ${ }^{24}$ The United Nations General Assembly approved a resolution on December 15, 1997, to adopt the International Convention for the Suppression of Terrorist Bombings, ${ }^{25}$ which penalizes bombing (which is defined) outside the state of which the perpetrator is a national. Most recently, the United Nations General Assembly also approved a resolution on December 9, 1999, to adopt the International Convention for the Suppression of Terrorist Financing. ${ }^{26}$

All these activities are considered terrorism, no matter who committed them, and no matter whether the acts were committed against a person's own government, a foreign government, or even against persons without connection to any government. The acts themselves are considered so reprehensible that they should be forbidden no matter what the context. Apart from these specific activities it has been impossible to agree on a definition of terrorism acceptable to the entire international community. ${ }^{27}$

In 1991 the International Law Commission of the United Nations unsuccessfully attempted to define terrorism ("acts against another state directed at persons or property and of such a nature as to create a state of terror in the minds of public figures, groups of persons or the general public"). ${ }^{28}$

As well, a resolution of the General Assembly of the United Nations ${ }^{29}$ states the following, which could be a useful and contemporary description of terrorism (in paragraph 1 and 2):

1. Strongly condemns all acts, methods and practices of terrorism as criminal and unjustifiable, wherever and by whom- 
ever committed; 2. Reiterates that criminal acts intended or calculated to provoke a state of terror in the general public, a group of persons or particular persons for political purposes are in any circumstances unjustifiable, whatever the considerations of a political, philosophical, ideological, racial, ethnic, religious or other nature that may be invoked to justify them;

There is no international body to prosecute persons who have been involved in terrorist activities. Only individual states take legal action against alleged terrorists, by prosecuting them, extraditing them, or applying immigration remedies against them. ${ }^{30}$

\section{Organized Crime}

In addition to a number of international and regional political initiatives undertaken by many countries to combat organized crime, there have also been major inroads made on the international legislative front. As a result of the 1994 World Ministerial Conference on Organized Transnational Crime in Naples, ${ }^{31}$ the General Assembly of the United Nations adopted on November 15, 2000, the United Nations Convention against Transnational Organized Crime and its two protocols, the Protocol to Prevent, Suppress and Punish Trafficking in Persons, Especially Women and Children, and the Protocol against the Smuggling of Migrants by Land, Sea and Air. ${ }^{32}$

As with terrorism, only national enforcement action is possible.

\section{Serious Criminality: The Canadian Immigration Legislation}

The main provisions in the present Immigration Act for the types of serious criminality that have been the subject of consideration in the international community-genocide, war crimes, crimes against humanity, terrorism, and organized crime - can be found in the portion that regulates the admissibility of persons to Canada.

The prohibition against persons involved in organized crime is set out in subparagraph 19(1)(c.2) of the Act and indicates that membership in an organization that has a pattern of criminality leads to a finding of inadmissibility; both present and past membership is covered by this section. ${ }^{33}$

The inadmissibility provisions for terrorism can be found in four subparagraphs, which together make a wide range of terrorist activity subject to scrutiny: any commission of terrorist activities carried out personally or as a member of a terrorist organization, whether these activities were done in the past or the present or will happen in the future. The operative sections are 19(1)(e)(iii), 19(1)(e)(iv)(C), 19(1)(f)(ii), and 19(1)(f)(iii)(B). ${ }^{34}$
Ensuring that persons who have been involved in genocide, war crimes, and crimes against humanity cannot enter Canada or, if they are in Canada, will be removed, is the subject of three provisions in the Act: subsections 19(1)(j), 19(1)(1), and 19(1.1). Subsection 19(1)(j) deals with persons who have been involved in such crimes directly or indirectly, ${ }^{35}$ while the combination of subsections $19(1)(1)^{36}$ and $19(1.1)^{37}$ goes further and makes inadmissible any high official of a regime that the Minister of Citizenship and Immigration has designated as a regime that was or is engaged in terrorism, genocide, war crimes, or crimes against humanity. So far, seven regimes have been designated:

- the Bosnian Serb regime between March 27, 1992, and October 10, 1996 (designated June 16, 1993, later extended on August 15, 1997)

- the Siad Barré regime in Somalia between 1969 and 1991 (designated October 12, 1993)

- the military governments in Haiti between 1971 and 1986, and between 1991 and 1994, except the period August-December 1993 (designated April 8, 1994)

- the former Marxist regimes of Afghanistan between 1978 and 1992 (designated October 21, 1994)

- the governments of Ahmed Hassan Al-Bakr and Saddam Hussein in power in Iraq since 1968 (designated September 3, 1996)

- the government of Rwanda under President Habyarimana between October 1990 and April 1994, as well as the interim government in power between April and July 1994 (designated April 27, 1998)

- the governments of the Federal Republic of Yugoslavia and the Republic of Serbia (under Milosevic) since February 28, 1998 (designated June 30,1999) 38 $^{38}$

It is not necessary to show that the persons were involved in all the activities described above, but only that there are reasonable grounds to believe that they were. The standard of proof of reasonable grounds is low: between mere suspicion and balance of probabilities. ${ }^{39}$ On the other hand, in order not to cast the net so wide that persons who have been on the periphery of organizations involved in nefarious activities are caught, all of these provisions, except subsection $19(1)(j)$, contain so-called exemption clauses that allow the Minister of Citizenship and Immigration to overcome the inadmissibility and allow landing or entry if the Minister judges it not to be detrimental to the national interest.

The Immigration Act does not address only terrorism, organized crime, genocide, war crimes, and crime against humanity in the context of admissibility. These concepts permeate all aspects of the processes set out in the Act. ${ }^{40}$ They can be found in the provisions dealing with eligibil- 
ity to refer a claim to the Convention Refugee Determination Division (CRDD) of the Immigration and Refugee Board, ${ }^{41}$ appeal rights to the Immigration Appeal Division (IAD) ${ }^{42}$ landing of refugees, ${ }^{43}$ access to the Post-Determination Refugee Claimant in Canada (PDRCC) process, ${ }^{44}$ removal from Canada, ${ }^{45}$ and the provisions regulating the special security proceedings and protection of information. ${ }^{46}$ They also play a role in the humanitarian and compassionate $(\mathrm{H} \& \mathrm{C})$ process. ${ }^{47}$

Serious criminality is also a factor for refugee determination as a result of the Schedule to the Immigration Act that incorporates exclusion clauses $\mathrm{E}$ and $\mathrm{F}$ of the 1951 Refugee Convention. Exclusion ground $\mathrm{F}$, which deals with criminality, does not allow persons who have been involved in crimes against peace, war crimes, crimes against humanity, serious non-political crimes, and acts against the principles and purposes of the United Nations to obtain refugee status.

\section{Serious Criminality: The Canadian Immigration Jurisprudence}

Terrorism

The courts in Canada have been as reluctant as the international community to define the term terrorism, which is used in subparagraphs 19(1)(e)(iii), 19(1)(e)(iv)(C), 19(1)(f)(ii), and 19(1)(f)(iii)(B) ${ }^{48}$ of the present Immigration Act. Instead of providing a definition, both the Appeal and the Trial Divisions of the Federal Court, in the Suresh case, and the Federal Court of Appeal in the Ahani ${ }^{49}$ case, make a number of propositions about terrorism:

- There is no need to define the term. "When one sees a 'terrorist act,' one is able to define the word."

- The term in not vague or imprecise. The term is defined in a dictionary as "using terror and violence to intimidate, subjugate, etc. especially as a political weapon or policy."

- The term terrorism or terrorist act must receive a wide and unrestricted interpretation.

- In general, attacks on civilians are terrorist attacks.

- Those who freely choose to raise funds to sustain terrorist organizations bear the same guilt and responsibility as those who actually carry out the terrorist acts. Persons who raise funds for the purchase of weapons, which they know will be used to kill civilians, are as blameworthy as those who actually pull the triggers.

- Terrorism includes the act of assassination directed at silencing political dissidents who seek to bring about change through the exercise of free expression..$^{50}$

\section{Membership}

The notion of "membership," which is used not only in some sections of the Immigration Act described above, ${ }^{51}$ but has also received judicial interpretation in the context of exclusion ground $\mathrm{F}(\mathrm{a}),{ }^{52}$ has been given the following parameters:

- To be a member of an organization, formal membership is not required. Simply belonging to such an organization is sufficient.

- An individual is a member of an organization if one devotes oneself full time or almost full time to the organization, or if one is associated with members of the organization, especially for a lengthy period of time.

- Belonging to an organization is assumed when people join voluntarily and remain in the group for the common purpose of actively adding their personal efforts to the group's cause. ${ }^{53}$

- There is no need to identify the specific acts in which the individual has been involved because of the notoriety and singular purpose of the group.

- Knowledge of the purpose of the organization can be imputed from the activities one is involved in and is presumed if one belongs to this type of organization. This presumption can be rebutted..$^{54}$

\section{Organized Crime}

The section dealing with organized crime has not yet received any judicial interpretation with respect to the substantive terms used in section 19(1)(c.2) $)^{55}$ although several judicial review applications that challenged the refusal or removal based on this section have been dealt with by the court on other grounds. ${ }^{56}$

Genocide, War Crimes, and Crimes against Humanity

\section{General}

The vast majority of the case-law that the Federal Court developed in the area of serious criminality has been in the area of complicity for crimes against humanity for exclusion ground $\mathrm{F}(\mathrm{a})$. The court has decided over eighty cases dealing with $F(a)$ matters since 1992, primarily to determine where to lay the boundaries for liability of persons who had not personally committed such atrocities.57

Apart from the contribution by the Federal Court to international law in war crimes and crimes against humanity in the area of complicity, most substantive law dealing with the crimes of genocide, war crimes, and crimes against humanity has been generated by the ICTY, the ICTR, ${ }^{58}$ and the negotiations surrounding the Statute of the Interna- 
tional Criminal Court.

The development of crimes under international law has not always taken place consistently. As a result, there is overlap between a number of crimes, such as between genocide and crimes against humanity; war crimes and crimes against humanity; crimes against humanity and terrorism; and war crimes and terrorism.

These crimes can be described as follows:

- Genocide: the deliberate and systematic destruction, in whole or in part, of a national, ethnic, racial, or religious group, whether committed in times of peace or in times of war, by state officials or by private individuals.

- Crimes against humanity: murder, extermination, enslavement, torture, and any other inhumane acts committed against civilians, in a widespread or systematic manner, whether or not the country is in a state of war, and regardless whether the act is in violation of the territorial law in force at the time. The acts may have been committed by state officials or private individuals, and against their own nationals or nationals of other states.

- War crimes: criminal acts committed during international armed conflicts (war between states) and civil wars, which violate the rules of war as defined by international law. These acts include the ill-treatment of civilian populations within occupied territories, the violation and exploitation of individuals and private property, and the torture and execution of prisoners.

\section{Differences between genocide and crimes against humanity}

Historically, genocide was considered a particularly reprehensible crime against humanity, and as a result every genocide is still also a crime against humanity; the reverse is not true, however. The difference between genocide and crimes against humanity is as follows:

- The intention for genocide is narrower, namely an "intent to destroy," while for crime against humanity it is "knowledge of an attack."

- The behaviour targeted for genocide is more reprehensible, namely the destruction "in whole or in part, of a group," while for crimes against humanity, it is "widespread or systematic attack."

- The circle of victims for genocide is narrower, namely "a national, ethnical, racial, or religious group," as opposed to "any civilian population" for crimes against humanity. ${ }^{59}$

\section{Differences between war crimes and crimes against humanity}

Traditionally, the difference between these two crimes was easier to identify.

War crimes could be committed only during a time of war between two countries. They could be committed only against persons who were nationals of the opposite side of the conflict. On the other hand, someone could commit a war crime even it was done as an isolated incident and even if the perpetrator was acting in an individual (and not based on state authority) capacity.

Crimes against humanity could be committed against any national but only as part of a widespread or systematic policy, action, or plan, and only if connected to the commission of a war crime by individuals acting on behalf of a state.

As a result of the fact that international law now includes as war crimes acts committed during non-international armed conflicts, and the fact that the requirements of the connection to a war and acting on behalf of a state have been eliminated in the concept of crimes against humanity, the lines between those crimes have become blurred. There are still some differences, however:

- Isolated reprehensible acts do not amount to crimes against humanity, while even one atrocity can result in the commission of a war crime. This does not mean that a single act can never be a crime against humanity, but it has to be shown that this one act was the result of the implementation of widespread or systematic policy.

- War crimes, even committed in a civil war, can occur only when a certain threshold of intensity has been reached between the two parties in this conflict. For instance, the actions of police officers conducting themselves violently during riots do not amount to war crimes. Crimes against humanity can occur in any setting: international wars, civil wars, and even in times of peace. This would mean that a particular activity, for instance a killing of a civilian during a civil war, could be both a war crime and a crime against humanity if the other requirements of each crime were fulfilled.

- While some of the enumerated prohibited acts can be both war crimes and crimes against humanity, other acts fall under one category only. For example, destruction of certain types of property can be a war crime but can never be a crime against humanity, while persecution is a crime against humanity but not a war crime. 


\section{Differences between crimes against humanity/war crimes and terrorist acts}

International law has determined that only certain narrowly defined activities amount to terrorism, although a recent agreement, the International Convention for the Suppression of Terrorist Bombings, has a wider application and penalizes bombings in public places, government facilities, public transportation systems, or infrastructure facilities. War crimes and crimes against humanity cover most of these terrorist activities but also include others that are not considered terrorism.

On the other hand, terrorist acts can occur in a context wider than crimes against humanity, since they need not be committed in a widespread or systematic manner and can be committed against persons and property. They are also wider in this context than war crimes because they can be committed both in time of war and peace. As with the overlap between war crimes and crimes against humanity, it is possible that one activity can fit the description of all three crimes at the same time, for instance where a person belongs to a group that has conducted a bombing campaign during a civil war.

\section{War Crimes, Genocide, and Crimes against Humanity: The Canadian Policy}

The Canadian policy is based on two distinct but related elements. The first one is that Canada will not be a safe haven for persons who have been involved in atrocities abroad. The second element is that in pursuing such persons, Canada will abide by its international obligations.

The no safe haven policy was most recently articulated as follows: "The message is clear. Those individuals who have committed a war crime, a crime against humanity or any other reprehensible act during times of conflict, regardless of when or where these crimes occurred, are not welcome in Canada." ${ }^{60}$

In international law, states incur obligations from the operation of conventional or customary international law. In conventional international law, the instruments that are applicable are the 1949 Geneva Conventions and Additional Protocols, the Genocide Convention, Torture Convention, and the "terrorism" conventions, the last two insofar as the activities mentioned in these conventions can also amount to war crimes or crimes against humanity. Crimes against humanity finds its source in customary international law.

The four Geneva Conventions ${ }^{61}$ are primarily directed towards international armed conflict, that is, armed conflict between two High Contracting Parties or situations of occupation of territories. The Conventions can also apply to non- international armed conflicts where the parties to the conflict have agreed to apply the provisions of the Conventions.

The four Geneva Conventions contain similar definitions of grave breaches or war crimes, that is, serious breaches of the obligations under the Conventions, and require High Contracting Parties to take the following measures with respect to grave breaches:

- enact legislation to provide penal sanctions for persons committing (or ordering to be committed) any of the grave breaches of the Convention

- search for persons alleged to have committed such grave breaches

- bring such persons, regardless of their nationality, before their own courts

On the last point, if the state prefers, it may, "in accordance with the provisions of its own legislation, hand such persons over for trial to another High Contracting Party concerned, provided such High Contracting party has made out a prima facie case." This is the basis for what is known as the prosecute or extradite provision of the Geneva Conventions.

Additional Protocol I, Article 88, imposes on High Contracting Parties the obligation to provide the greatest measure of assistance in connection with criminal proceeding brought in relation to grave breaches of the Conventions or of the Protocol. States are required to co-operate in extradition and consider the extradition request of the State in whose territory the alleged offence has occurred.

While there is no positive obligation on State Parties to the Genocide Convention to prosecute persons accused of committing genocide unless the genocide was committed in the State's territory, there is a positive obligation on States Parties to grant an extradition request "in accordance with their laws and treaties."

In addition to being covered by the grave breaches provisions of the Geneva Conventions, the prohibition against torture is also covered by the Convention against Torture and Other Cruel, Inhuman or Degrading Treatment or Punishment. This convention applies during times of armed conflict, as well as during times of peace.

The convention places an obligation on State Parties to make acts of torture offences under their criminal law and, if persons alleged to have committed such offences are found on the State's territory, without exception and whether or not the offence was committed in its territory, must submit the case to its competent authorities for prosecution or extradition.

At the moment, there are eleven conventions that regulate terrorism and to which Canada is a party. ${ }^{62}$ They all contain a duty to extradite or prosecute, of which the latter 
is expressed as follows: "The Contracting State in the territory of which the alleged offender is found shall, if it does not extradite him, be obliged, without exception whatsoever and whether or not the offence was committed in its territory, to submit the case to its competent authorities for the purpose of prosecution. Those authorities shall take their decision in the same manner as in the case of any ordinary offence of a serious nature under the law of that State."

Although it is argued that there is a general duty to prosecute or extradite those accused of crimes against humanity, there is no convention that covers crimes against humanity stating this. Therefore, one must look to customary international law to determine whether there exists an obligation to extradite or prosecute persons who have committed crimes against humanity.

Although Canada is not party to the Convention on the Non-Applicability of Statutory Limitations to War Crimes and Crimes against Humanity, ${ }^{63}$ this Convention could be considered, in some respects, to be an expression of customary international law. The Convention does not contain a prosecute or extradite provision but reflects the general obligation on States to extradite those accused of war crimes in accordance with international law. There are also two United Nations General Assembly Resolutions that deal with the issue of war crimes and crimes against humanity in this context. The first one is the 1970 un Resolution on War Criminals, ${ }^{64}$ which refers only to extradition in the same general terms as the convention mentioned in the preceding paragraph. The second is the 1973 un Resolution on Principles of International Co-operation in the Detection, Arrest, Extradition and Punishment of Persons Guilty of War Crimes and Crimes against Humanity. ${ }^{65}$ This resolution states that war crimes or crimes against humanity, wherever committed, are subject to investigation and prosecution. Although it states that, as a general rule, prosecution should occur in the countries in which the offences were committed, it does not exclude prosecution in other countries. There is no explicit prosecute or extradite provision, but there is a call for cooperation among states in the prosecution of such crimes. Furthermore, whether un General Assembly resolutions constitute customary international law is a controversial issue among international legal scholars and not free from doubt by any means.

The statutes of the two International Criminal Tribunals, established by the un Security Council and thus binding on all states, do not contain prosecute or extradite provisions for alleged criminals within their jurisdiction. There are, however, obligations on States to cooperate with the Tribunals in the investigation and prosecution of accused persons, as well as the obligation to transfer accused persons to the Tribunals. ${ }^{66}$ The same will apply to the International Criminal Court when its Statute comes into force. ${ }^{67}$

The following conclusions that underlie Canada's policy on international obligations can be drawn from the above:

- There is a duty to extradite or prosecute persons who have committed war crimes during international armed conflicts.

- There is also a duty to extradite persons who have committed genocide.

- Likewise, there is a duty to transfer persons who committed war crimes or crimes against humanity in the former Yugoslavia since 1991, or in Rwanda in 1994, to the International Criminals Tribunals established for this purpose.

- There is at the moment no positive legal obligation to prosecute or extradite people who have committed war crimes during non-international armed conflicts or who have committed crimes against humanity unless:

v these same acts also amount to torture

- these acts fall within the definitions of the "terrorism" conventions

In order to implement the two elements of the Canadian policy, three departments have created war crimes sections. The RCMP and the Department of Justice have had such sections since 1987 but have dealt primarily with alleged war criminals from the Second World War era, until recently when they also expanded into the investigation for possible prosecution of persons involved in modern-day war crimes-those atrocities committed since wwII. The Department of Citizenship and Immigration established a war crimes section only in 1996, and its mandate is limited to applying immigration remedies, such as overseas refusal, exclusion, refusal of landing and deportation to modernday war criminals. ${ }^{68}$

The war crimes sections of the three departments have developed a modus operandum that brings together efficiently and coherently the two elements of the Canadian war crimes policy. All allegations received by the three departments are examined by an operations group with members of these three sections. This operations group has been and will be making an assessment of each individual allegation to determine whether the allegation should be investigated by the RCMP/Justice for possible prosecution, or by the Department of Citizenship and Immigration in order to apply immigration remedies. If the allegation discloses a possible war crime, genocide, a terrorist activity, or torture, the file is automatically referred to the RCMP/ Justice. If the allegation discloses a crime against human- 
ity the file is not automatically referred, but a further examination is conducted to assess the seriousness of the crimes against humanity and only for the most serious ones the RCMP/Justice will open their own file. So far, over 800 allegations of atrocities have been examined by the interdepartmental operations group, of which about to per cent were referred to the RCMP/Justice. ${ }^{69}$

Referral of an allegation is only one step in the cooperative effort of the three war crimes sections to implement the war crimes policy. If a file has been referred from CIC, CIC will continue processing the file up to the point of removal; if a person can be removed but is also the subject of a RCMP/Justice investigation, the operations group will make an ad hoc decision on how to proceed with that particular file at that time, taking into account such factors as the state of the criminal investigation versus allowing a person who has been determined to be a war criminal under the immigration system to remain in Canada. On the other hand, a referral to the RCMP/Justice will not necessarily result in the laying of criminal charges; most cases that are referred arise out of allegations or evidence that are not admissible in criminal court, so that other corroborative evidence needs to be found to support the case. If diligent investigative efforts have been made and there is still insufficient evidence to lay charges, the file is referred to CIC in order to use immigration remedies against the subject of these allegations.

This system ensures that Canada's international obligations to investigate and prosecute persons who have been involved in atrocities are respected without compromising the policy of zero tolerance for war criminals, by using other immigration remedies if it is not possible or necessary to utilize the extradition or prosecution option, thereby preventing Canada from becoming an attractive place for human rights abusers to hide. ${ }^{70}$

\section{Bill c-31 and Its Impact}

On April 6, 2000, the government introduced Bill C-31 to replace the present Immigration Act entirely and permit the immigration and refugee system to be more responsive to the needs and challenges of the future. ${ }^{71}$ The underlying premise of the Bill was to open the front door to genuine immigrants and refugees but close the back door to persons who do not need or who abuse Canada's immigrant and refugee system.

The Bill did not contain any additional provisions that specifically deal with war criminals..$^{72}$ For the most part, all the provisions that deal with war criminals, which have been effective in the present Immigration Act, were been trans- ferred to the Bill. In a number of instances, the Bill contained sections that had application to suspected war criminals as well as to other categories of persons involved in very serious criminality, such as organized crime or terrorism. The purpose of these sections was to streamline some of the processes that are often cumbersome and lengthy, as well as to eliminate the distinctions in the immigration processes that now exist between organized crime, terrorism, and war crimes. ${ }^{73}$

Some of these new provisions ensured that:

- access to the IAD was prohibited entirely for all serious criminals ${ }^{74}$

- exclusion was extended from the notion of refugees to the new concept in the Bill of persons in need of protection ${ }^{75}$

- persons whose refugee claim had been refused by the CRDD could not enter the refugee stream again; this would have included persons who had been excluded for the commission of war crimes and crimes against humanity. At the moment, it is possible for persons who have been rejected to make subsequent claims ${ }^{76}$

- it would no longer have been necessary to have the Minister of Citizenship and Immigration declare that it is contrary to the national interest to deny access to the CRDD to people involved in very serious criminality; an inadmissibility finding that a person belonged to such a category would have been is sufficient for this purpose ${ }^{77}$

- the threshold for removing persons to their country of origin who have been found to be refugees but also have committed very serious criminal activities was changed from "danger to security of Canada" to either "danger to the security of Canada or "contrary to the national interest" 78

- for the Pre-Removal Risk Assessment, the Minister would have taken into account (when considering an application for protection from persons who were serious criminals or who were excludable) whether such persons would pose a "danger to the security of Canada" or if it would be contrary to the national interest to allow such an application ${ }^{79}$

\section{Conclusion}

The last decade has seen a trend towards international criminalization of a number of activities that the global community has come to view as reprehensible from a moral point of view while at the same time politically highly destabilizing. A concerted effort has taken place to address these activities by developing international legal instruments as well as enforcement mechanisms. The result is 
uneven. On the war crimes front, which includes genocide and crimes against humanity, there has been real progress in bringing the law into accordance with the political reality of civil wars and the wide abuse of human rights, at the same time as the international community and individual states have started to enforce those legal norms. The situation with terrorism and organized crime is different, for now there are a number of international treaties of which the most recent ones against terrorism and the ones pertaining to organized crime could have a large impact, but for the moment have limited application, namely only when individual states are willing to act. It has not yet been possible to develop an international enforcement mechanism to deal with these two types of crimes.

Canada's experience mirrors the international one. In the area of war crimes and crimes against humanity, both the judiciary and the Canadian government have developed a sophisticated model for dealing with persons involved in such crimes. The Federal Court jurisprudence in the area of complicity for crimes against humanity gave a wide interpretation to exclusion ground $\mathrm{F}(\mathrm{a})^{80}$ and was ahead of - although not at odds with—international law, ${ }^{81}$ while the government has developed a method of ensuring that all allegations of war crimes are dealt with appropriately, either by prosecution or immigration remedies.

The Federal Court has also been willing to freely interpret certain concepts related to terrorism and organized crime but has avoided tackling the most vexing issue-a definition of the term terrorism itself. And it has not been necessary for the government to determine which law to apply—criminal or civil—for such activities, since the conventions with the most impact-the latest two terrorist conventions and the organized crime convention-have not yet been ratified by Canada.

It would appear that when taking together all the serious criminal activities discussed, the major sources of investigations are persons applying abroad and refugee claimants in Canada. In Canada a number of processes are used for refugee claimants or refugees against whom there are allegations of serious criminality. In the immigration context, not only is exclusion clause F used but also the noneligibility provisions, if they are claimants, while refusal of landing, denial of appeal rights, and reliance on the refoulement provisions are levelled against them if they have obtained refugee status. Some of them are also investigated for criminal purposes if they had a connection to genocide, war crimes, and torture, or if their activities related to crimes against humanity have been particularly heinous.

In using immigration remedies to bring war criminals to justice, Canada is trying to adhere to all its international obligations, which sometimes are not easy to reconcile. A good example is the double obligation in the Torture Convention, one that contains a positive duty to prosecute or extradite a person who might have been involved in acts of torture, ${ }^{82}$ while the second, a negative one, prohibits refoulement to torture. ${ }^{83}$ Both provisions could very well apply to a refugee claimant who is excluded because of involvement in torture, and who is then investigated unsuccessfully by the RCMP/Justice for possible criminal charges because there is not sufficient evidence to meet the much higher burden in a criminal trial. A decision needs then to be made whether this person should be removed to his country of origin while he has raised the prospect of being tortured upon his return there. These are the cases for which there is no easy answer but where the government, academics, and non-governmental organizations can work together to bring about an acceptable solution for all concerned, but especially for the victims of such a person who might also be living in Canada and whose past agony will revive if they come eye to eye with their torturer. ${ }^{84}$

It will become necessary to ensure that persons involved in very serious criminality are taught that their crimes do not pay. One way of doing this is to have a system in which similar to national criminal law systems, perpetrators are investigated and then taken to justice. Whether they are brought to justice by the international community or by the courts and tribunals of individual countries matters less than the fact that perpetrators know that at some point in the future their actions will have consequences and that they will not be able to continue to do their deeds with impunity. What does matter in this war against impunity is the effectiveness of the remedies employed. Although is quite arguable that deporting a serious criminal to his or her country of origin might not be seen as a real solution in the bigger question of providing a deterrent, exacting retribution, or compensating the victims, like other efforts made in this area in the last decade, it is a first and important step to show possible perpetrators that their lives will not be made easy when trying to come to Canada.

If Canada's example of a combination of immigration remedies with the likelihood of criminal prosecution for cases with sufficient evidence to prosecute-as is now the case for persons involved in war crimes or crimes against humanity-will have resonance in the future in other countries and will result in similar action taken elsewhere, one hopes that the world will become a smaller place for human rights abusers and other serious criminals to commit their reprehensible activities unchecked. 


\section{Notes}

1. See Canada's War Crimes Program, Annual Report 1999-20oo, Appendix F (see cIC website at <http://www.cic.gc.ca/english/ pub/war20oo-e.html >). The number of refugee claimants investigated between 1992 and 2000 for atrocities is 2940; intervention for exclusion $\mathrm{F}(\mathrm{a})$ was sought by the Minister of Citizenship and Immigration in 356 cases; of these cases in which the Minister intervened, the Convention Refugee Determination Division of the Immigration and Refugee Board excluded a person 225 times. While this number is only in relation to exclusion clause $\mathrm{F}(\mathrm{a})$, this clause is used by far the most of all the exclusion clauses. For instance, at the Federal Court level, there have been over 80 cases decided in respect to $\mathrm{F}(\mathrm{a}$ ) (or $\mathrm{F}(\mathrm{c})$ cases dealing with crimes against humanity) between 1992 and 2001, while there have only been only $7 \mathrm{~F}(\mathrm{~b})$ and 6 other $\mathrm{F}(\mathrm{c})$ cases at that level.

2. An attempt was made to include this crime in the Statute of the International Criminal Court but it was unsuccessful; see note 30 for more details.

3. See for instance Roy Gutman and David Rieff, eds., Crimes of War, What the Public Should Know (New York \& London: W.W. Norton \& Company, 1999).

4. See Christopher Greenwood, "Historical Development and Legal Basis" in Dieter Fleck, ed., The Handbook of Humanitarian Law in Armed Conflict (New York: Oxford University Press, 1999) 12-23.

5. Namely the Sawoniuk case. For a commentary, see Ian Bryan and Peter Rowe, "Role of Evidence in War Crimes Trial: The Sawoniuk Case" in Yearbook of International Humanitarian Law 2, 1999: 307-323. Another case, Serafimovich, was not successful. Canada launched four cases between 1985 and 1990; they were the cases of Finta, Pawlowski, Reistetter, and Grujicic. Only the Finta case was completed at trial where he was acquitted, and the decision was upheld by both the Ontario Court of Appeal and the Supreme Court of Canada. (For trial decision, see 69 O.R. $\left(2^{\text {nd }}\right) 557$ (Ont. H.C.); for the pre-trial motions, see 50 C.C.C. (3d) 236 (Ont. H.C.); for the Ontario Court of Appeal decision, see 73 C.C.C. (3d) 65 (O.C.A.); for the Supreme Court decision, see [1994] 1 S.C.R. 701 (S.C.C.)). There have been three criminal prosecutions in Australia, namely the cases of Berezovsky, Wagner, and Polyukhovich, none of which resulted in a conviction; the decision of the High Court of Australia on pre-trial motions in the last case can be found in 101 Australian Law Reports 545 and 91 International Law Reports 1.

6. For Canada, see Canada's War Crimes Program, Annual Report 1999-2000 at 8-9; for the U.S., see <http://www.us-israel.org/ jsource/holocaust/rosenbaum.html $>$.

7. See $<$ http://www.un.org/law/icc/statute/romefra.htm>.

8. Canada ratified the ICC Statute on July 7, 2000, as the fourteenth country to do so (see <http://www.un.org/law/icc/statute/ status.htm>).

9. See Colin Warbrick, Elena Martin Salgado, and Nicholas Goodwin, "The Pinochet Cases in the United Kingdom" in Yearbook of International Humanitarian Law 2, 1999: 91-117.

10. See <http://www.un.org/ICTy/indictment/english/miliig90524e.htm>.
11. As well, the Pinochet case is cited as inspiration to attempt to bring the ex-dictator of Chad, Hissene Habre, to trial in Senegal where he is living at the moment; see the Washington Post, November 27, 2000, 3 .

12. For instance by the Center for Justice \& Accountability in San Francisco, $<$ http://www.impunity.org $>$.

13. For an overview of the various means of bringing war criminals to justice see Yves Beigbeder, Judging War Criminals (New York \& London: MacMillan Press, 1999); for truth commissions, see Human Rights Quarterly 16, 4: 597-675, articles by Priscilla B. Hayner, "Fifteen Truth Commissions—1974 to 1994: A Comparative Study," and Mark Ensalaco, "Truth Commissions for Chile and El Salvador: A Report and Assessment."

14. Apart from the Statutes of the Nuremberg and Tokyo Tribunals after the World War II and the more recent Statutes of the ICTY (see <http://www.un.org/ICTY >), ICTR $(<\mathrm{http}: / /$ www .ictr.org $>)$ and ICC (<http://un.org/law/icc $>)$, there have also been a number of international treaties that regulate the conduct during a war, including the prohibition against war crimes, namely the 1949 Geneva Conventions and their Additional Protocols of 1977; there are four Geneva Conventions: the Geneva Convention for the Amelioration of the Condition of the Wounded and Sick in Armed Forces in the Field (Geneva I); the Geneva Convention for the Amelioration of the Condition of Wounded, Sick and Shipwrecked Members of Armed Forces at Sea (Geneva II); the Geneva Convention for the Amelioration of the Condition of Wounded, Sick and Shipwrecked Members of Armed Forces at Sea (Geneva III); and the Geneva Convention relative to the Protection of Civilian Persons in Time of War (Geneva Iv). The text of the four Conventions can be found in Schedules I to IV to the Geneva Conventions Act, R.S.C. 1985, Chapter G-3. The articles dealing with war crimes are articles 50 (Geneva I), 51 (Geneva II), 130 (Geneva III), and 147 (Geneva IV) which is the most encompassing. The war crimes provisions of the 1949 Geneva Conventions have been supplemented by the 1977 Additional Protocol I, articles 11 and 85. For a discussion of the post-World War II case-law, see Rikhof, "War Crimes, Crimes against Humanity and Immigration Law," (1993) $19 \mathrm{Imm}$. L.R. $\left(2^{\text {nd }}\right) 18$, at $30-46$.

15. A number of other activities have also been the subject of international treaties that ask parties who have signed these treaties to criminalize the described behaviour in their national legislation and to ensure that persons who have been involved in that behaviour are either prosecuted or extradited to a country that is willing to prosecute those persons. Examples of such activities are the unlawful use of chemical weapons; incitement of hate, based on racial discrimination; slavery; drug trafficking on a large scale or with an international dimension; severe pollution of coastlines; interference with submarine cables; mercenarism; and acts against the safety of United Nations and associated personnel. See Cheriff Bassiouni, Aut Dedere, Aut Judicare (The Hague: Kluwer Law International, 1995), who sets out twenty-four categories of such crimes in the table of contents and on page 73. The difference is that genocide, terrorism, organized crime, and torture have a higher profile internationally in that they are either the subject of an enforcement mecha- 
nism (such as for genocide where the ICTY and ICTR have put perpetrators of this crime on trial), a monitoring system (such as for torture where the UNCAT, the United Nations Committee against Torture, is active) or of international co-operation, often under the auspices of the United Nations (terrorism and organized crime). As both the Torture Convention and UNCAT system are well known, they will not be further discussed in this article.

16. The Convention on the Prevention and Suppression of the Crime of Genocide was adopted by General Assembly Resolution and opened for ratification in 1948. It came into force on January 12, 1951; Advisory Opinion of the International Court of Justice of May 28, 1951, on Reservations to the Convention on the Prevention and Punishment of the Crime of Genocide, International Court of Justice Reports (1951), at page 23.

17. Case ICTR-96-4-I

18. The ICTy has issued one judgment so far in which genocide had been charged (Jelisic, Case IT-95-10-T, December 14, 1999) and the ICTR four judgments, namely in the Akayesu case (Case ICTR-96-4-T, September 2, 1998); the Kayishema/Ruzindana case (Case No. ICTR-95-1-T, May 21, 1999); the Rutaganda case (ICTR96-3-T, December 6, 1999); and the Musema case (Case ICTR96-13-T, January 27, 2000).

19. The Convention for the Suppression of Unlawful Seizure of Aircraft (860 UNTs 105) and the Convention for the Suppression of Unlawful Acts against the Safety of Civil Aviation (974 UNTS 178).

20. The Protocol for the Suppression of Unlawful Acts at Airports Serving International Civil Aviation (ILM, Volume XxviI, 627).

21. The Convention on the Prevention and Punishment of Crimes against Internationally Protected Persons Including Diplomats (1035 UNTS 168; ILM, Volume VIII, 41).

22. The International Convention against the Taking of Hostages (1316 UNTS 206; ILM, Volume XVIII, 1456).

23. The Convention on the Physical Protection of Nuclear Material (ILM, Volume XVIII, 1422).

24. The Convention for the Suppression of Unlawful Acts against the Safety of Maritime Navigation (ILM, Volume xxviI, 668) and the Protocol for the Suppression of Unlawful Acts against the Safety of Fixed Platforms Located on the Continental Shelf (ILM, Volume XxviI, 685).

25. un Doc. A/52/653, Annex; article 2 provides that "any person commits an offence within the meaning of this Convention if that person unlawfully and intentionally delivers, places, discharges or detonates an explosive or other lethal device in, into or against a place of public use, a State or government facility, a public transportation system or an infrastructure facility: (a) with the intent to cause death or serious bodily injury; or (b) with the intent to cause extensive destruction of such a place, facility or system, where such destruction results or is likely to result in major economic loss." The terms State or government facility, infrastructure facility, explosive or other lethal device, and place of public use are defined in article 1.

26. UNGA Resolution 54/109. At the moment, work is being done to prepare a Convention on the Suppression of Acts of Nuclear Terrorism (see A/AC.252/L3) and a comprehensive convention on international terrorism (see UN Doc. A/C.6/55/L.2).
27. There have been some attempts in Europe and the United States. The European Convention on the Suppression of Terrorism of 1977 defines terrorism in article 1 as follows ( $<$ http://conventions .coe.int/treaty/en/treaties/html/ogo.htm $>$ ):

For the purposes of extradition between Contracting States, none of the following offences shall be regarded as a political offence or as an offence connected with a political offence or as an offence inspired by political motives:

a. an offence within the scope of the Convention for the Suppression of Unlawful Seizure of Aircraft, signed at The Hague on 16 December 1970;

b. an offence within the scope of the Convention for the Suppression of Unlawful Acts against the Safety of Civil Aviation, signed at Montreal on 23 September 1971;

c. a serious offence involving an attack against the life, physical integrity or liberty of internationally protected persons, including diplomatic agents;

d. an offence involving kidnapping, the taking of a hostage or serious unlawful detention;

e. an offence involving the use of a bomb, grenade, rocket, automatic firearm or letter or parcel bomb if this use endangers persons;

f. an attempt to commit any of the foregoing offences or participation as an accomplice of a person who commits or attempts to commit such an offence.

In the U.K., the Terrorism Act, which came into force February 19, 2001 (<http://www.parliament.the-stationery-office.co.uk/ $\mathrm{pa} /$ pabills.htm $>$ ) defines terrorism in section 1 as:

(1) The use or threat of action where (a) the action falls within subsection (2), (b) the use or threat is designed to influence the government or to intimidate the public or a section of the public, and (c) the use or threat is made for the purpose of advancing a political, religious or ideological cause.

(2) Action falls within this subsection if it (a) involves serious violence against a person, (b) involves serious damage to property, (c) endangers a person's life, (d) creates a serious risk to the health or safety of the public or a section of the public, or (e) is designed seriously to interfere with or seriously to disrupt an electronic system.

(3) The use or threat of action falling within subsection (2) which involves the use of firearms or explosives is terrorism whether or not subsection (1)(b) is satisfied.

The U.S. defines this term in section 212(a)(3)(B)(ii) of the Immigration and Nationality Act (<http://www.ins.usdoj.gov/ graphics/lawsregs/ina.htm $>$ ) thus:

As used in this Act, the term "terrorist activity" means any activity which is unlawful under the laws of the place where it is committed (or which, if committed in the United States, would be unlawful under the laws of the United States or any State) and which involves any of the following:

(I) The highjacking or sabotage of any conveyance (including an aircraft, vessel, or vehicle).

(II) The seizing or detaining, and threatening to kill, injure, or continue to detain, another individual in or- 
der to compel a third person (including a governmental organization) to do or abstain from doing any act as an explicit or implicit condition for the release of the individual seized or detained.

(III) A violent attack upon an internationally protected person (as defined in section 1116(b)(4) of title 18, United States Code) or upon the liberty of such a person.

(Iv) An assassination.

(v) The use of any-

(a) biological agent, chemical agent, or nuclear weapon or device, or

(b) explosive or firearm (other than for mere personal monetary gain), with intent to endanger, directly or indirectly, the safety of one or more individuals or to cause substantial damage to property.

(vi) A threat, attempt, or conspiracy to do any of the foregoing.

28. ILM, volume $\mathrm{XXX}$, page $1592 / 3$.

29. A/RES/51/120 of January 16, 1997.

30. Although the Rome Statute or ICC Statute was adopted on July 17, 1998, an Ad Hoc Committee on the Establishment of an International Criminal Court had already been operating in 1995, followed by a Preparatory Committee on the Establishment of an International Criminal Court between 1996 and 1998. This latter Committee included in its 1996 report the following crimes under the jurisdiction of an ICC: international terrorism, apartheid, torture, hostage taking, illicit drug trafficking, attacks against United Nations and associated personnel and serious threats against the environment, apart from genocide, war crimes and crimes against humanity (UN Doc. A/51/22). A report by this Committee during its meeting from March 16 to April 3, 1998, still included other crimes such as terrorism, crimes against United Nations and associated personnel and drug trafficking (see un Doc. A/AC. 249/1998/CRP.8, pages 17/18). Even before the two special committees started their work, the International Law Commission had already been asked by the General Assembly of the United Nations in 1991 to work on a draft statute for an International Criminal Court. The ILC obliged in 1994 and included in its draft an article 20, which purported to give the court jurisdiction over two types of crimes, the first being inherent jurisdiction crimes over existing crimes under international law (such as genocide, aggression, serious violations of law and customs in armed conflict, and crimes against humanity), the second being jurisdiction over a number of exceptionally serious crimes of international concern, namely terrorist activities, war crimes, torture, apartheid, and drug trafficking (See un Doc. A/CN.4/L.491/Rev.2 and General Assembly Official Records, 49th Session, Supplement No. 10, pages $66 / 79,145 / 146$ and 439 ). Eventually only three crimes remained within the ICC's jurisdiction: genocide, crimes against humanity and war crimes (articles 6-8 of the ICC Statute), while the door is left open to add the crime of aggression when a definition for that crime has been agreed upon (article 5.2 of the ICC Statute). The trial of two Libyan nationals in the Netherlands is not being conducted by an international criminal court but by a Scottish court, which has been transplanted to the Netherlands as result of an international compromise; it applies Scottish law and procedure before Scottish judges (see $<$ http://www .law.gla.ac.uk/lockerbie/index.cfm>).

31. un Doc. E/Conf/88.

32. UN Doc. GA/9822, which is the press release announcing it; UN Doc. A/RES/55/25 is the General Assembly Resolution; un Doc. $\mathrm{A} / 55 / 383$ contains the Convention and its Protocols as appendices.

33. Section 19(1)(c.2) reads, "persons who there are reasonable grounds to believe are or were members of an organization that there are reasonable grounds to believe is or was engaged in activity that is part of a pattern of criminal activity planned and organized by a number of persons acting in concert in furtherance of the commission of any offence under the Criminal Code or Controlled Drugs and Substances Act that may be punishable by way of indictment or in the commission outside Canada of an act or omission that, if committed in Canada, would constitute such an offence, except persons who have satisfied the Minister that their admission would not be detrimental to the national interest."

34. Section 19(1)(e) says, "persons who there are reasonable grounds to believe ... (iii) will engage in terrorism, or (iv) are members of an organization that there are reasonable grounds to believe will ... (C) engage in terrorism," while section 19(1)(f) reads, " $(f)$ persons who there are reasonable grounds to believe ... (ii) have engaged in terrorism, or (iii) are or were members of an organization that there are reasonable grounds to believe is or was engaged in ... (B) terrorism."

35. Section 19(1)(j) states, "persons who there are reasonable grounds to believe have committed an offence referred to in any of sections 4 to 7 of the Crimes against Humanity and War Crimes Act." The Crimes against Humanity and War Crimes Act (SC 2000, Ch. 24) was assented to on June 29, 2000, and came into force on October 23, 2000; section 55 of this Act contains the consequential amendments to the Immigration Act, subsection 55(1) for paragraph 19(1)(j), and subsection 55(2) for paragraph $19(1)(1)$. As a result of this Act, the crime of committing genocide is a crime in Canada for the first time (as opposed to the crime of advocating genocide, which can be found in section 318(1) of the Criminal Code).

36. " $[\mathrm{P}]$ ersons who are or were senior members of or senior officials in the service of a government that is or was, in the opinion of the Minister, engaged in terrorism, systematic or gross human rights violations, or any act or omission that would be an offence under any of sections 4 to 7 of the Crimes against Humanity and War Crimes Act, except persons who have satisfied the Minister that their admission would not be detrimental to the national interest."

37. "For the purposes of paragraph $(1)(l)$, 'senior members of or senior officials in the service of a government' means persons who, by virtue of the position they hold or have held, are or were able to exert a significant influence on the exercise of government power and, without limiting its generality, includes (a) heads of state or government; 
(b) members of the cabinet or governing council;

(c) senior advisors to persons described in paragraph (a) or (b);

(d) senior members of the public service;

(e) senior members of the military and of the intelligence and internal security apparatus;

(f) ambassadors and senior diplomatic officials; and

$(g)$ members of the judiciary."

The federal court held in the case of Adam (F.C.T.D., IMM3380-96, August 29, 1997; upheld on appeal by F.C.A, A-19-98, January 11, 2001) that this subsection contains a non-rebuttable presumption, meaning that if a person is found to have occupied the position mentioned, that fact in itself will result in inadmissibility even if there is nothing to show that the person actually exercised influence on the regime in question. The only other decision that has examined sections 19(1)(1)/19(1.1) has been Esse (F.C.T.D., IMM-4523-96, January 16, 1998), which dealt with the 19(1)(1) exemption clause and the process required when using it.

38. Canada's War Crimes Program, Annual Report 1999-200o, Appendix C.

39. See Sivakumar [1994] 1 F.C. 433 (F.C.A) and Owens (IMM-566899, October 11, 2000).

40. See Van Kessel, “Canada's Approach towards Exclusion Ground ${ }_{1} \mathrm{~F}$ ” in Peter J. van Krieken, ed., Refugee Law in Context: The Exclusion Clause (The Hague: T.M.C. Asser Press, 1999) 287293.

41. Section 46.01(1)(e)(ii), which prevents persons involved in terrorists activities, genocide, war crimes, and crimes against humanity from having access to the refugee determination process if the Minister of Citizenship and Immigration is of the opinion that it would be contrary to the public interest. This section does not apply to organized crime.

42. Sections $70(4)(b), 70(5), 70(6)$, and $77(3.01)(b)$, which prevent access to the Immigration Appeal Division of the Immigration and Refugee Board completely for organized crime reasons, but allows limited access, namely on fact and law but not with regard to all circumstances of the case, for reasons related to security and war crimes (unless indirectly as a result of the issuance of a section 40.1 certificate that has been approved by the Federal Court, in which case no appeal to the IAD is allowed).

43. Section 46.04(3), which prevents landing of persons who have been found to be refugees if they or any of their dependants have been involved in any type of serious criminality.

44. The PDRCC process can be accessed by persons who have been found not to be refugees by the CRDD, and it uses a wider definition of risk than the 1951 Refugee Convention, which is applied by the CRDD. Section (a)(vi) of the definition of "member of the post-determination refugee claimants in Canada class" of the Immigration Regulations prevents a person from accessing this program if (s)he has been excluded for $1 \mathrm{~F}$ reasons or has been involved in serious criminality (except organized crime); section 11.4 of the Immigration Regulations provides the process for landing under this program.

45. Section 53(1)(b), if the Minister is of the opinion that the refugee constitutes a danger to the security of Canada. This section does not apply to organized crime. The Minister balances the risk that the person faces upon return to the country of origin versus the danger to the security of Canada. Apart from this section in the Immigration Act, persons can also invoke article 3 of the Torture Convention to prevent removal to their country of origin. The process used in assessing such a claim is one of the issues before the Supreme Court in the Suresh and Ahani cases (see note 47 ).

46. Sections 39(2), 39(4), 40(1), 40.1(1), 40.1(7), 81(2)(a), and $81(2)$ (b). The protection of information provisions (sections 39(5), 40.1(5.1), 77(3.2), 81(1)(4), and 82.1(10)) are all congruent with the substantive provisions re inadmissibility to which they refer with the exception of section 82.1(10), of which section $19(1)(j)$ is not a part.

47. See the Inland Processing (IP) Manual, ch. 5, paras. 3.3, 6.5, 9.1, 9.7, and 9.12. Serious criminality is to be balanced against humanitarian and compassionate considerations.

48. Terrorism is only one of the several other concepts related to inadmissibility based on security grounds in the present Immigration Act, such as 19(1)(e)(i), (ii), 19(1)(f)(i), 19(1)(g), or $19(1)(\mathrm{k})$, but this paper will not discuss these concepts, although there is case-law regarding those provisions. Some of these cases, such as Al Yamani ([1996] 1 F.C. 174 and IмM-1919-98, March 9, 2000, and Moumdjian, A-1065-88, July 19, 1999), discuss primarily whether the term subversion in 19(1)(e) and section 19(1)(g) as a whole are constitutional. The term subversion was found to violate the Charter by being too vague constitutionally, but the judge then found that section 1 of the Charter could be used to save the provision so that in the final analysis this term was found to be constitutional (Al Yamani, IMm-1919-98, March 9, 200o). Section 19(1)(g) was found to be constitutional except for one portion: the part that makes members of an organization that is likely to engage in acts of violence inadmissible ( $\mathrm{Al}$ Yamani [1996], 1 F.C. 174, and Moumdjian). Incidentally, all aspects of section 19(1)(f) have been found to be constitutional (McAllister v. Canada (108 F.T.R 1); Singh, Iмm-1647-98, May 6, 1998; Suresh, IMM-117-98, June 11, 1999; and Suresh, A-415-99, January 18, 2000). Section 19(1)(f)(i) was also discussed in the $\mathrm{Qu}$ case (Iмм-5114-98, April 20, 2000; case is under appeal), specifically the meaning of the term espionage or subversion against democratic government, institutions or processes. The court found that espionage means "gathering of information in a surreptitious manner," while subversion means "accomplishing change by illicit means or for improper purposes related to an organization." The court found that a person who reports on the activities of a Chinese student organization at an university in Canada is, while engaging in espionage and subversion, not inadmissible, because a student organization is not included in the term democratic government institutions and processes. Similarly, this paper will not discuss procedural or evidentiary issues such as the burden of proof; the case of Davinder Singh, IMM-1490-99, December 24, 1999, provides some guidance in this matter. Last, section 19(1)(f) contains a clause that allows the Minister to provide an exemption to the application of this section if the admission of the person would not be detrimental to the national interest. This clause has been 
judicially reviewed twice, in the Kashmiri (37 C.R.R. (2d) 264) and the Kishavarz (IMM-1692-99, August 20, 2000) cases.

49. Suresh, FCTD, DES-3-95, November 14, 1997, page 14-16; Suresh, FCA, A-415-99, January 18, 2000, paragraph 43; Ahani, FCA, A413-99, January 18, 2000, paragraph 18; the Supreme Court of Canada granted leave to hear both cases on May 25, 2000.

50. See also for some of these propositions Baroud v. Canada (98 F.T.R. 99) and McAllister v. Canada (108 F.T.R 1). In the Ali Noor case (FCTD, IMM-1814-95) terrorism is not defined, but the judge is of the opinion on pages 2 and 3 of the decision that an attack on the person of a diplomat is clearly an act of terrorism.

51. Section 19(1)(c.2), 19(1)(e)(IV)(C), and 19(1)(1)(f)(III)(B).

52. This is a result of the fact that the Federal Court has distinguished between two types of complicity, depending to which kind of organization a person belonged. If a person belonged to an organization with the single and brutal purpose of violating human rights, the threshold to attract liability for being complicit is low, namely only membership with a knowledge of the purpose of that organization. If, on the other hand, the organization was only incidentally involved in the commission of atrocities, a more active role is required in order to be complicit. For an analysis of the case-law in this area, see Rikhof, "Exclusion Clauses: The First Hundred Cases in the Federal Court" (1996) 24 Imm.L.R. $\left(2^{\text {nd }}\right)$ 137, 152-158. Since the publication of that article, another forty-one cases have examined the issue of complicity for $1 \mathrm{~F}(\mathrm{a})$ applying the same principles, although the court has expanded and clarified the case-law with respect to hybrid organizations, which have both legitimate and nefarious purposes (see Mehmoud (F.C.T.D., IMM-1734-97, July 7, 1998); Cardenas (1994) 23 Imm. L.R.(2d) 244, 74 F.T.R. 214 (F.C.T.D.), Kudjoe (F.C.T.D., IMM-5129-97, December 4, 1998), and (in the context of organized crime) Chiau (F.C.A, A-75-98, December 12, 2000, paragraph 59). For case-law regarding the parameters of brutal, single purpose organizations see Nejad (1994) 85 F.T.R. 312 (F.C.T.D.); Saridag (1994) 85 F.T.R. 307 (F.C.T.D.); Diaz (1995) 94 F.T.R. 237 (F.C.T.D.); Demiye (F.C.A, September 6, 1995); Aden (F.C.T.D., IMM-2912-95, August 14, 1996); Shakarabi (F.C.T.D., IMM-1371-97, April 1, 1998); Hajialakhani (F.C.T.D., IMM3105-97, September 11, 1998) and Zoya (F.C.T.D., IMm-5256-99, November 20, 2000). The other cases since 1996 are (all by the FCTD, unless indicated): Cabrera, IMM-1991-95, February 9, 1996; Alza, Iмм-3657-94, March 26, 1996; Aden, Iмм-2912-95, August 14, 1996; Bazargan, A-400-95, September 18, 1996 (FCA); Rasuli, IMM-3119-95, October 25, 1996; Siad, A-226-94, December 3, 1996 (FCA); Liu, IMM-1304-96, December 5, 1996; Say, IMM-2547-96, May 16, 1997; Suliman, IMM-2829-96, June 13, 1997; Berko, IMM4462-96, September 29, 1997; Ledezma, Iмм-3785-96, December 1, 1997; Bamlaku, Iмм-846-97, December 30, 1997; Cortez Cordon, Iмм-1889-97, April 14, 1998; Ofuq, Iмм-1828-97, May 29, 1998; Guardado, IMM-2344-97, June 2, 1998; Kiared, IMM-317297, August 24, 1998; Cabrera, IMM-4657-97, December 23, 1998; Paz, IMM-226-98, January 6, 1999; Quinonez, IMM-2590-97, January 12, 1999; Yang, IMM-1372-98, February 9, 1999; Saavedra, IMM4742-98, April 7, 1999; Salazar, IMM-977-98, April 16, 1999; Khera, IMM-4009-98, July 8, 199; Grewal, IMM-4674-98, July 23, 1999; Nagra, IMM-5534-98, October 27, 1999; Szekely, IMM-6032-98, De- cember 15, 1999; Sumaida, A-800-95, January 7, 2000 (FCA); Wajid, IMм-1706-99, May 25, 2000; Bermudez, IMM-1139-99, June 13, 2000; Osagie, IMM-3394-99, July 13, 2000; Mohsen, IMM-324699, August 15, 2000; Rivera Aguilar, IMM-4491-99, August 16, 2000; Ordonez, IMM-2821-99, August 30, 2000; Albuja, IMM-356299, October 23, 2000; Musansi, IMM-5470-99, January 21, 2001; and Kennedy Loordu, IMM-1258, January 25, 2001.

53. Saridag (1994) 85 F.T.R. 307 (F.C.T.D.); Shakarabi (F.C.T.D., IMM1371-97, April 1, 1998); Suresh (F.C.T.D., DEs-3-95, November 14, 1997, page 12); Chiau (F.C.T.D., IMM-1441-96, February 23, 1998, page 17/18, upheld by F.C.A, A-75-98, December 12, 2000); and Owens (F.C.T.D., IMM-5668-99, October 11, 2000).

54. Saridag (1994) 85 F.T.R. 307 (F.C.T.D.); Aden (F.C.T.D., IMM-291295, August 14, 1996).

55. Except the notion of "membership" in the Chiau case, see footnote 54.

56. In the Dolly Shuk Ching Chan case, at issue were the notions of functus, the fettering of discretion by the visa officer and the constitutionality of section 82.1(10), which was used to protect information (F.C.T.D., IMM-6477-93, June 17, 1996), all of which were decided in favour of the government. In the Kwong Yau Yuen case, section 19(1)(c.2) was found to be constitutional (F.C.T.D., IMM-5272-97, February 4, 1999; upheld by the F.C.A, December 21, 2000, A-152-99); in the Miranda Yuen case, the decision revolved around the issue of what constituted a valid marriage (F.C.T.D., IMM-916-97, November 13, 1997); in the Chun Wai Lam case (F.C.T.D., IMM-2842-97, July 31, 1998) where the procedure with respect to a section 70(5) Minister's opinion was examined; and in the Kwong Kwok Kin case (F.C.T.D., IMM3804-99, December 15, 2000), where the level of procedural fairness during a visa application involving section 19(1)(c.2) was found to have been appropriate.

57. See note 53. The court also defined what distinguished crimes against humanity from domestic crimes in the Sivakumar case in accordance with international law, see footnote 28 . For a commentary, see Rikhof, "Crimes against Humanity, Customary International Law and the International Tribunals for Bosna and Rwanda" (1996) National Journal of Constitutional Law (NJCL), Volume 6.2, pages 233-269. The court has not been so successful in coming to grips with the nature of war crimes, which it has examined four times in the last eight years in the cases of Gonzalez (FCA, A-48-91; for commentary see Rikhof, "The Treatment of the Exclusion Clauses in Canadian Refugee Law" (1995) 24 Imm.L.R. (2 $\left.{ }^{\text {nd }}\right), 31$ at 49-52); Balta (F.C.T.D., IMM2459-94, January 27, 1995); Cibaric (1995, 105 F.T.R. 304; for a commentary see Rikhof, "Exclusion Clauses: The First Hundred Cases in the Federal Court" (1996) 24 Imm.L.R. $\left(2^{\text {nd }}\right)$ 137, at 145-146; and most recently the Bermudez case (F.C.T.D., IMM1139-99, June 13, 2000, under appeal) where the judge held that war crimes cannot be committed during a civil war, which is contrary to international jurisprudence in this area, namely the Appeal Chamber's Decision on the Defence Motion for Interlocutory Appeal on Jurisdiction, October 2, 1995, paragraphs 128-134 (Case IT-94-1).

58. There have been eight judgments on substantive matters by the ICTY Trial Chamber (Erdomovic, Tadic, Celebici, Furundzija, 
Aleksovski, Jelisic, Kupreskic, and Blaskic) and five by the Appeal Chamber (Erdemovic, Tadic, Aleksovski, Furundzija, and Celebici); at the ICTR there have been seven final decisions, all by the Trial Chamber, four that were judgments and sentences (Akayesu, Kayishema/Ruzindana, Rutaganda, and Musema), while three were sentences after a guilty plea (Kambanda, Serushago, and Ruggiu).

59. Compare articles 6 and 7 of the Statute of the International Criminal Court, see note 4.

6o. Canada's War Crimes Program, Annual Report 1999-200o, 2.

61. See note 4.

62. See notes 9-16.

63. This Convention was adopted by the United Nations General Assembly Resolution and opened for ratification on November 26, 1968 (Resolution 2391 [XXIII]) and came into force on November 11, 1970.

64. UNGA Resolution 2712 (xxv).

65. UNGA Resolution 3074 (XXVIII).

66. Article 29 of the ICTY Statute; Article 28 of the ICTR Statute; transfer to the international tribunals from Canada is now possible thanks to amendments to the Extradition Act SC 1999, ch. 18 , section 1 , part (d) of the definition of State or entity.

67. Articles 87 and 89 of the ICC Statute.

68. Canada's War Crimes Program, Annual Report 19992000, 3-6 and $10-12$.

69. Ibid., 7-8.

70. This approach was commented upon favourably by the Committee against Torture in its consideration of the third periodic report of Canada (un Doc. CAT/C/XXV/Concl.4, paragraph 4(c), 22 November, 2000) while the Committee recommends that Canada "prosecute every case of an alleged torturer in a territory under its jurisdiction where it does not extradite that person and the evidence warrants it, and prior to any deportation" (paragraph 6(c)).

71. As a result of the fact that a federal election was called on October 22, 2000, the Bill died on the order paper of the House of Commons, but has been tabled on February 21 as Bill c-11.

72. The provisions dealing with inadmissibility based on organized crime, terrorism, genocide, war crimes, and crimes against humanity could be found respectively in sections 33 (1) (a) (while 33(1)(b) added the specific crimes of people smuggling, trafficking in persons, and money laundering, to the already existing general concept of organized crime);30(1)(c)/30(1)(f); and $31(1)(a)$ (for what is now section 19(1)(j)); and 31(1)(b) (for what is now section 19(1)(1)).

73. Canada's War Crimes Program, Annual Report 1999-200o, 20-21.

74. Section 59(1).

75. Section 91.

76. Section 95(1)(a).

77. Section $95(1)(d)$.

78. Section $108(2)(b)$.

79. Section $107(4)(b)$.

8o. The interpretation of $\mathrm{F}(\mathrm{b})$ and $\mathrm{F}(\mathrm{c})$ by the courts has been narrower than that of $F(a)$. For F(b), the Federal Court has indicated that it has to be a capital crime or a very grave punishable act. There is a strong presumption that any crime, the equiva- lent of which carries a maximum penalty of more than ten years, is a serious crime. So far, only drug trafficking in cocaine or heroine, sexual assault, bombing, and coups d'état (including activities such as delivering weapons and seizing radio and TV stations) have been held to be serious crimes for the purposes of article $1 \mathrm{~F}(\mathrm{~b})$. Shoplifting, even when committed in a habitual fashion, is not a serious F(b) crime. See Malouf (1994) $26 \mathrm{Imm}$. L.R.(2d) 20, 86 F.T.R. (F.C.T.D.), overturned (1995) 190 N.R. 230 (F.C.A); Shamlou (1995) 32 Imm. L.R. (2d) 135, 103 F.T.R. 241 (F.C.T.D.); Gil (1994) 174 N.R. 292 (F.C.A) at 309; Brzezinski (F.C.T.D., IMM-1333-97, July 8, 1998); Moreno (F.C.T.D., IMM-144798, February 5, 1999); Chan (F.C.A, A-294-99, July 24, 2000). As well, this exclusion clause does not apply in a situation where a person has already been convicted of the crimes under consideration and has already served his sentence (Chan). The only part where the court gives an element of $\mathrm{F}(\mathrm{b})$ a wide interpretation is in the notion of what constitutes a political crime (Gil). The situation is even more pronounced for $\mathrm{F}(\mathrm{c})$, where as a result of the decision by the Supreme Court of Canada in Pushpanathan ([1998] 1 S.C.R. 982), at the moment only five types of activities can be considered contrary to the purposes and principles of the United Nations: terrorism, forced disappearance, torture, apartheid, and hostage taking. For an analysis and commentary on the judgment, see Rikhof, "Purposes, Principles and Pushpanathan: The Parameters of Exclusion Ground $1 \mathrm{~F}(\mathrm{c})$ of the 1951 Refugee Convention as Seen by the Supreme Court of Canada" (1999) 37. (46) AWR (Association for the Study of the World Refugee Problem), No. 4/1999, 182.

81. As can be seen by the statement of the Iсту Appeals Chamber on the issue of aiding and abetting in the Tadic case, paragraph 229, July 15, 1999, (Case IT-94-1).

82. Article 7.

83. Article 3.

84. This is not an academic situation. There have been instances where victims of persons who were involved in atrocities have come forward and demanded action by the government. The best known case is that of Leon Mugesera who has been accused and found inadmissible for incitement to genocide in Rwanda. For more details on the immigration case, see William A. Schabas, "Mugesera v. Minister of Citizenship and Immigration, Canadian Immigration and Refugee Board Appellate Decision on Expulsion of Alien for Inciting Genocide in Rwanda" (2000) 93 American Journal of American Law (AJIL) 529-533.

Mr. Rikhof is special counsel and policy advisor of the War Crimes Division of the Department of Citizenship and Immigration. Mr. Rikhof has written extensively on war crimes and exclusion law. The opinions expressed in this paper are entirely his own and do not necessarily represent any policies or opinions of the government of Canada. 